\title{
Soil physical and hydraulic properties in the Donato stream basin, RS, Brazil. Part 1: Spatial variability
}

\author{
Tirzah M. Siqueira ${ }^{1}$, José A. S. Louzada ${ }^{2}$, Olavo C. Pedrollo², Nilza M. dos R. Castro² \&
}

Marquis H. C. de Oliveira ${ }^{3}$

${ }^{1}$ Universidade Federal de Pelotas. Pelotas, RS, Brasil. E-mail: tirzahsiqueira@hotmail.com (Corresponding author) - ORCID: 0000-0002-6576-0217
${ }^{2}$ Universidade Federal do Rio Grande do Sul. Porto Alegre, RS, Brasil. Email: louzada@iph.ufrgs.br - ORCID: 0000-0002-0551-2043; olavopedrollo@gmail.com -
ORCID: 0000-0001-7264-0259; nilza@iph.ufrgs.br - ORCID: 0000-0001-8061-3541
${ }_{3}^{3}$ Água e Solo Estudos e Projetos LTDA. Porto Alegre, RS, Brasil. E-mail: mhenriquee@hotmail.com - ORCID: 0000-0003-0568-837X

\begin{abstract}
The processes of water flow and water storage in the soil are directly associated with its hydraulic properties, which may vary significantly in space. Therefore, this study aimed to perform a spatial analysis of saturated hydraulic conductivity and the parameters of the soil water retention curve in the Donato basin, located in the municipality of Pejuçara, in the northwest region of the state of Rio Grande do Sul, Brazil,

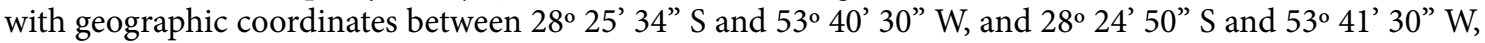
$590 \mathrm{~m}$ of altitude. Undisturbed soil samples (total of 55) were collected from August to November of 2012. The results have demonstrated larger variability for hydraulic conductivity and for the parameter $\alpha$ of the retention curve, and allowed identifying that the high spatial heterogeneity of the studied variables could be associated with factors such as climate, land use and land cover, sampling errors, sampling grid density and also the level of soil compaction.
\end{abstract}

Key words: saturated hydraulic conductivity, retention curve, soil heterogeneity

\section{Propriedades físico-hidráulicas do solo na bacia do arroio Donato, RS, Brasil. Parte 1: Variabilidade espacial}

RESUMO: Os processos de fluxo e armazenamento de água no solo estão diretamente associados às suas propriedades hidráulicas, as quais podem variar significativamente no espaço. Por estas razões, este trabalho objetivou realizar uma análise espacial da condutividade hidráulica saturada e dos parâmetros da curva de retenção de água no solo na bacia do arroio Donato, localizada no município de Pejuçara, na região Noroeste do estado do Rio Grande do Sul, entre coordenadas geográficas $28^{\circ} 25^{\prime} 34^{\prime \prime}$ S e $53^{\circ} 40^{\prime} 30^{\prime \prime}$ O, e 28 $24^{\prime} 50^{\prime \prime} \mathrm{S}$ e 53 41' 30" O, 590 m de altitude. Amostras de solo indeformadas (total de 55) foram coletadas de agosto a novembro de 2012. Os resultados revelaram maior variabilidade para a condutividade hidráulica saturada e para o parâmetro $a$ da curva de retenção, e permitiram identificar que a grande heterogeneidade espacial das variáveis analisadas pode estar associada a fatores tais como clima, uso e cobertura do solo, erros de amostragem, adensamento da malha amostral e também ao grau de compactação do solo.

Palavras-chave: condutividade hidráulica saturada, curva de retenção, heterogeneidade do solo 


\section{INTRODUCTION}

Plant development is strongly related to water availability, which depends on its flow and storage in the soil. However, the flow and storage of water are directly associated with the hydraulic properties of the soil (Hu et al., 2007; Coppola et al., 2009).

These properties can vary significantly in space (Taskinen et al., 2008). Thus, it is crucial that the spatial variability of soil hydraulic properties for being accounted for in agrohydrological models. Such models can allow different irrigation regimes (if applicable) and different land use managements to be established.

In addition, it is known that hydraulic variables are difficult to obtain in the field, require long time and expensive equipment, skilled labor and, due to their variability, require many samplings that can hardly be extrapolated.

In this context, one of the major challenges in soil water flow modeling is to quantify the spatial variability of physical and hydraulic properties, such as soil water retention curve and hydraulic conductivity, since they are extremely heterogeneous.

Because they are crucial in modeling, these properties have been evaluated by several authors in relation to water movement in the vadose and/or saturated zone ( $\mathrm{Hu}$ et al., 2007; Taskinen et al., 2008; Coppola et al., 2009; Champo
\& Zamarrón, 2010; Paleologos \& Sarris, 2011; Santos et al., 2012; Furtunato et al., 2013; Fang et al., 2016; Montzka et al., 2017). The understanding of these variables is important, being required in studies on the efficiency of irrigation techniques, drainage and agricultural productivity.

Based on the foregoing, this study aimed to perform a spatial analysis of the saturated hydraulic conductivity $\left(\mathrm{K}_{\mathrm{sat}}\right)$ and soil water retention curve parameters (RC) in the Donato stream basin, located in the most important agricultural region of RS, Brazil.

\section{Material ANd Methods}

The study area is located in the municipality of Pejuçara, in the northwest region of the RS, Brazil, with geographic coordinates between $28^{\circ} 25^{\prime} 34^{\prime \prime} \mathrm{S}$ and $53^{\circ} 40^{\prime} 30^{\prime \prime} \mathrm{W}$, and $28^{\circ}$ $24^{\prime} 50^{\prime \prime} \mathrm{S}$ and $53^{\circ} 41^{\prime} 30^{\prime \prime} \mathrm{W}, 590 \mathrm{~m}$ altitude and comprises the Donato stream basin, with an area of $1.10 \mathrm{~km}^{2}$. This basin is part of a set of sub-basins of the Potiribu river, which is a contributor to the left bank of the Ijuí river, the latter being an affluent of the left bank of the Uruguay river (Figure 1).

The soils of the Donato stream basin are predominantly Oxisol and Ultisol with high clay content $(>60 \%)$, characterized by being well drained and deep (Castro et al., 2000).
A.

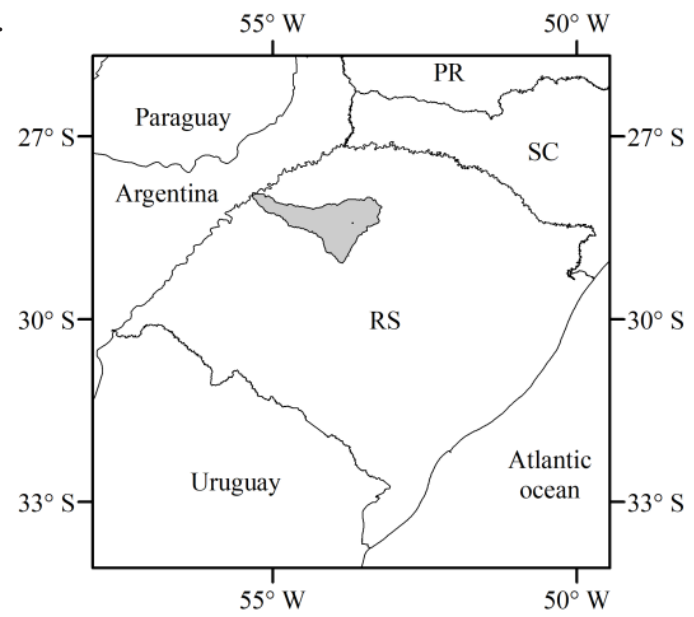

B.

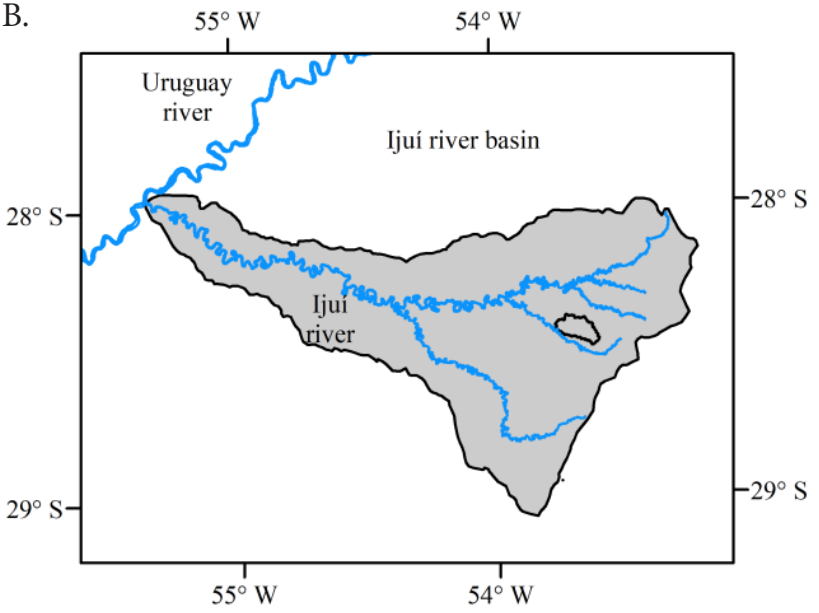

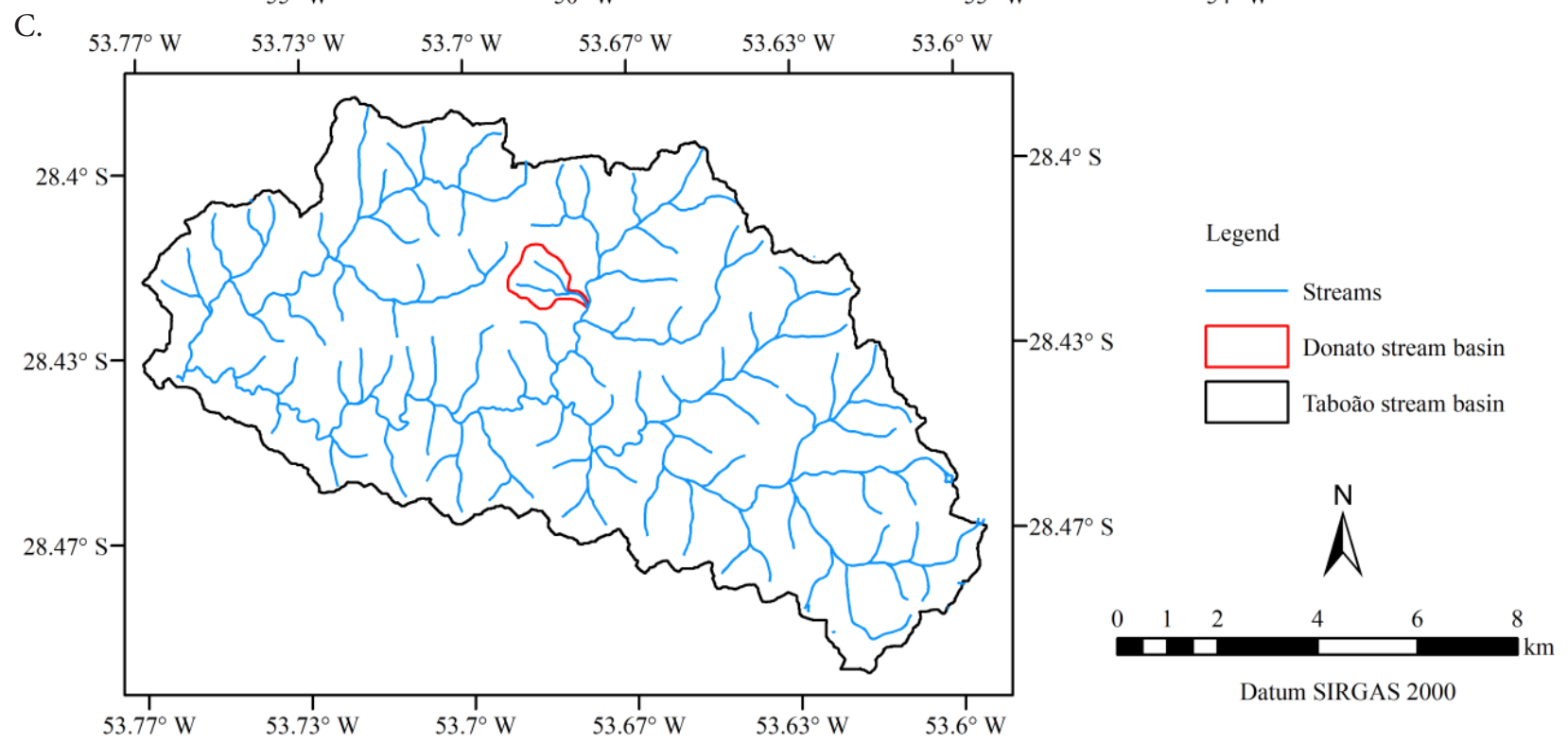

Figure 1. Donato stream basin location : Rio Grande do Sul state (A), Ijuí river basin (B) and Taboão and Donato stream basins (C) 
The soil use is essentially agricultural with the practice of direct cultivation throughout the basin area, with wheat (Triticum spp.), oats (Avena sativa) and soybean (Glycine max) being the most common crops. All crops are non-irrigated, and soybean is cultivated in the summer, while during the winter the farmers cultivate wheat and oats in the basin.

Three sets of samples were collected in August, October and November of 2012. During the first sampling, oats and wheat were being cultivated on the area, in the second sampling the soil was covered by only the remaining straw of these crops and in the third one soybean was already being cultivated, approximately $40 \mathrm{~cm}$ tall.

A regular grid was established covering all basin area. The soil was sampled at the crossing points of the grid, with regular spacing of $140 \mathrm{~m}$ and the most distant samples were collected in a regular spacing of $200 \mathrm{~m}$, making a total of 55 points (Figure 2). These samples complement the study of Medeiros (2004), which determined the soil water retention curves in 23 of the 55 points of this study. These 23 curves refer to the depth of $30 \mathrm{~cm}$ and were also used in this study.

In each of the 23 points where soil samples were already collected by Medeiros (2004) to obtain the retention curve, only one additional sample per point was collected to determine the saturated hydraulic conductivity. In the other points, two samples were collected, one to determine the soil water retention curve and the other to determine the saturated hydraulic conductivity.

The Richards chamber method was applied to determine the water retention curve (RC), considering the matric potentials of $-10,-30,-50,-70,-100,-150,-200,-250,-300$ and $-500 \mathrm{kPa}$. For the determination of $\mathrm{K}_{\mathrm{sat}}$, the variable head permeameter was used. Therefore, the variables analyzed were the soil saturated hydraulic conductivity and the soil water retention curve parameters $n, \alpha, \theta_{\text {sat }}$ and $\theta_{\text {res }}$, fitted according to the model of Genuchten (1980), defined by:

$$
\theta(\mathrm{h})=\theta_{\text {res }}+\left(\theta_{\text {sat }}-\theta_{\text {res }}\right)\left(1+|\alpha \mathrm{h}|^{\mathrm{n}}\right)^{-\mathrm{m}}
$$

where:

$\theta(\mathrm{h})$ - soil moisture associated with a given matric potential $\left(\mathrm{cm}^{3} \mathrm{~cm}^{-3}\right)$;

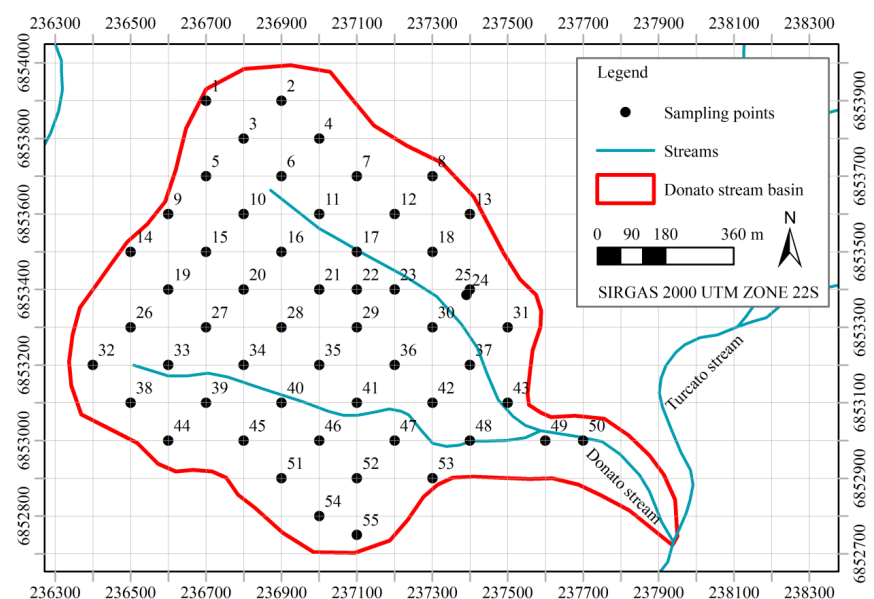

Figure 2. Grid of soil sample collection points in the Donato stream basin h - matric potential, cm;

$\theta_{\text {sat }} \quad$ - saturated soil water content, $\mathrm{cm}^{3} \mathrm{~cm}^{-3}$;

$\theta_{\text {res }}$ - residual soil water content, $\mathrm{cm}^{3} \mathrm{~cm}^{-3}$; and,

$a, \mathrm{n}$ and $\mathrm{m}$ - empirical shape parameters of the soil water retention curve $\left(\mathrm{cm}^{-1}\right.$, dimensionless, dimensionless), where $\mathrm{m}=1-(1 / \mathrm{n})$.

The RETC software (Genuchten et al., 1991) was used to fit the retention curve and determine the parameters of Eq. 1.

\section{Results AND Discussion}

The location maps of $\mathrm{K}_{\text {sat }}$ and the fitted parameters of the Genuchten (1980) soil water retention curve model allow a better visualization of the spatial distribution of the variables analyzed (Figure 3). Some variables were pre-transformed, such as $\mathrm{K}_{\text {sat }}$ (Figure $3 \mathrm{~A}$ ) and the parameter a (Figure $3 \mathrm{~B}$ ), to facilitate future treatment of these data. Blue points on the $\mathrm{K}_{\text {sat }}$ map represent the locations for which the saturated hydraulic conductivity value was very low and undetectable during the permeameter test.

These points represent the most critical areas for agricultural management, since they are associated with soil compaction processes. The basin area is predominantly of low hydraulic conductivity, with few dispersed samples of high values. As mentioned by Santos et al. (2012), the soil textural class and the agricultural cultivation conditions also contribute to high soil heterogeneity.

Higher variability was observed for saturated water content (Figure 3D) along the entire basin, while residual water content (Figure 3E) does not change much because the RETC model sets it equal to zero in most cases to continue fitting the other parameters. The spatial distribution of $\theta_{\text {sat }}$ values may also be related to the types of soils located in the basin, all Oxisols, which are characterized by being porous, but susceptible to compaction (Bergamin et al., 2010). Additionally, the authors cite that compaction in Oxisols diminishes the total porosity and macroporosity. This explains why higher $\theta_{\text {sat }}$ values were obtained along the springs, where the soil is less compacted.

Due to the fact that they are clayey soils, it is possible that this fact explains why, in general, at points where $\mathrm{K}_{\text {sat }}$ is smaller, $\theta_{\text {sat }}$ is higher. This is because clay particles do not facilitate infiltration near saturation, reducing hydraulic conductivity and causing the soil to lose water through evaporation. Moreover, according to Hu et al. (2008), soil water flow is more affected by clay content when the soil becomes dry, which happened during the first soil sampling. All samples of lower $\theta_{\text {sat }}$ values located in the northwestern portion of the basin (Figure 3D) were obtained when the soil was very dry, during the drought that began in November 2011 and continued until August 2012.

Regions of high and low a values were also observed along the area (Figure 3B). This parameter directly influences the air-entry pressure and its value may be greater than this pressure (Arraes, 2014). Its influence on the water retention curve is a translation, indicating that the lower the value of $\alpha$, the greater the matric potential associated with a specific soil moisture. Thus, the highest values of this parameter in Figure 3B 

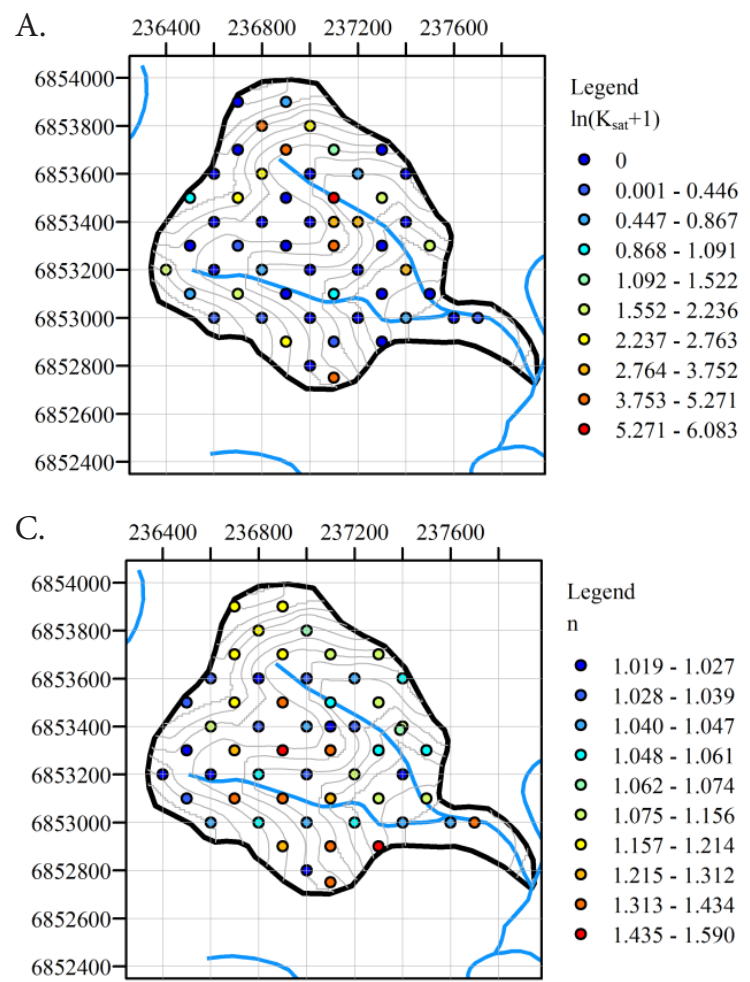

Legend

- $1.019-1.027$

- $1.028-1.039$

- $1.040-1.047$

- $1.048-1.061$

- $1.062-1.074$

- $1.075-1.156$

- $1.157-1.214$

- $1.215-1.312$

- $1.313-1.434$

- $1.435-1.590$

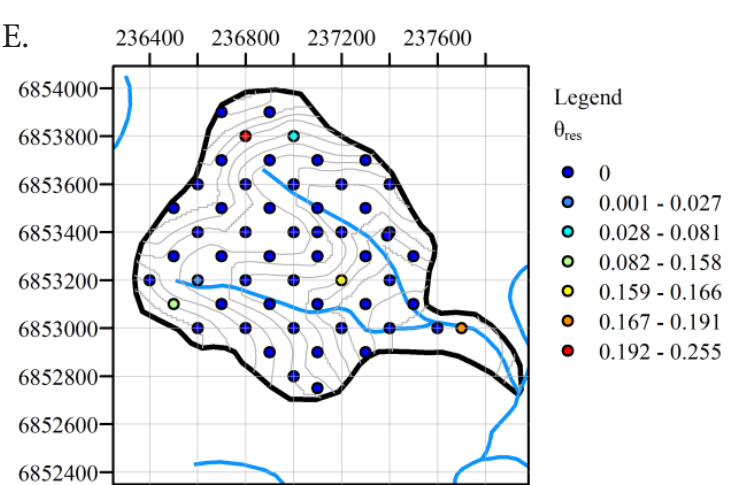

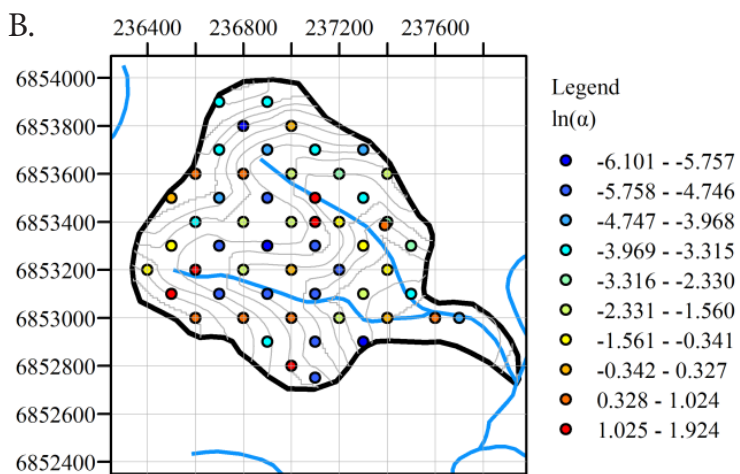
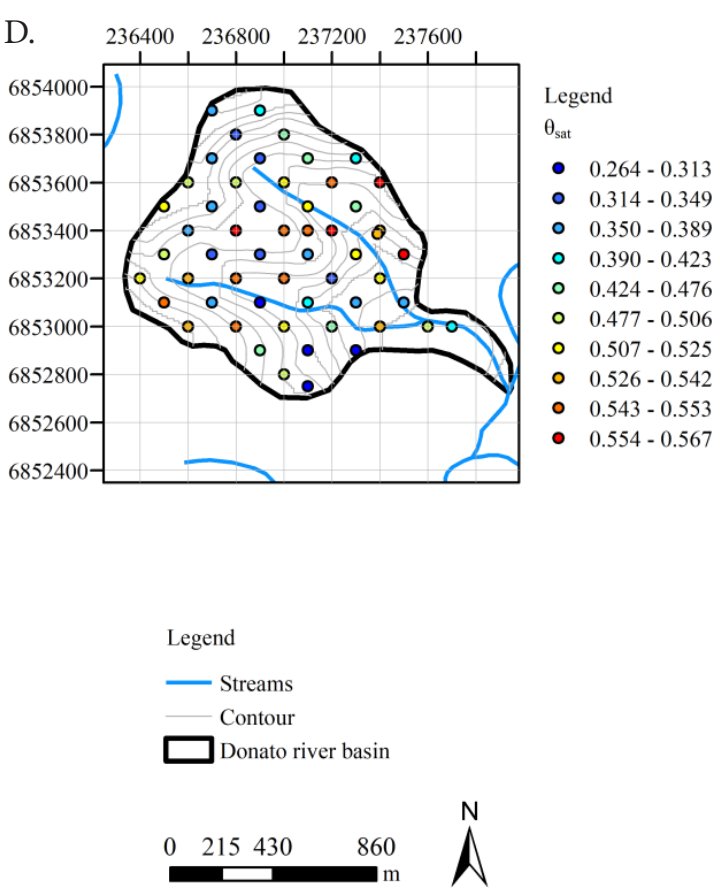

SIRGAS 2000 UTM ZONE 22S

Figure 3. Location maps of the soil physical and hydraulic properties: $\ln \left(K_{\mathrm{sat}}+1\right)(\mathrm{A}), \ln (\alpha)(B)$, parameter $n(C)$, saturated soil water content $\theta_{\text {sat }}(D)$, residual soil water content $\theta_{\text {res }}(E)$

indicate areas where the soil is probably less compacted and also generally coincide with the highest $\mathrm{K}_{\text {set }}$ values (Figure 3A).

On the other hand, the fitted values of the parameter $n$ (Figure 3C) indicated intermediate spatial variability, due to the small amplitude of the data, between 1.0 and 1.2. This parameter controls the slope of the water retention curve and the higher the value of $\mathrm{n}$, the steeper the water retention curve will be. It is also influenced by the level of soil compaction. Furthermore, as shown by Arraes (2014), soil water flow is more sensitive to this parameter than to $a$ and, therefore, must be obtained with greater precision, which is justified, considering its spatial variability.

These maps highlight that the spatial variability of the variables in the basin area is important and should not be disregarded, since $\mathrm{K}_{\text {sat }}$ and water retention curve are hydraulic properties that affect the soil water flow. Table 1 shows the statistical summary of the 55 samples of $\mathrm{K}_{\text {sat }}$ and the water retention curve parameters, without data transformations.

The sample variance for $\alpha$ and $K_{\text {sat }}$ parameters are highest, due to the presence of some very high values in certain regions. This result is in agreement with the work of Coppola et al. (2009), who
Table 1. Statistical summary of the 55 samples of $\mathrm{K}_{\mathrm{sat}}$ and the water retention curve parameters

\begin{tabular}{|c|c|c|c|c|c|}
\hline Statistics & $\underset{\left(\mathrm{Gm}^{-1}\right)}{\alpha}$ & n & $\frac{\theta_{\mathrm{sat}}}{\left(\mathrm{cm}^{3}\right.}$ & $\frac{\theta_{\mathrm{res}}}{\mathrm{m}^{-3} \mathrm{)}}$ & 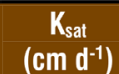 \\
\hline lean & 0.921 & 1.145 & 0.455 & 0.016 & 25.455 \\
\hline inimum & 0.002 & 1.019 & 0.264 & 0.000 & 0.000 \\
\hline & 6.849 & 1.590 & 0.567 & 0.255 & 437.414 \\
\hline & & 1.065 & 0.494 & 0.0 & 0.300 \\
\hline & & 1.0 & 0.373 & 0.0 & 0.000 \\
\hline & & 1.194 & 0.535 & 0.000 & 6.897 \\
\hline & & 0.0 & 0.008 & 0.003 & 5530.436 \\
\hline tand & 1.594 & 0.141 & 0.089 & 0.052 & 74.367 \\
\hline & 1.219 & 0.1 & 0.162 & 0.000 & 6.897 \\
\hline Coefficient of variation $(\%)$ & 173.2 & 12.3 & 19.5 & 324.1 & 292.2 \\
\hline
\end{tabular}

also found higher coefficients of variation for $\mathrm{K}_{\text {sat }}$ and $\alpha$. Moreover, the results of these authors indicate that the $\mathrm{RC}$ parameters have a great impact on the prediction of uncertainties and can not be ignored in stochastic simulations of variables important to groundwater flow.

The small variance of $\theta_{\text {sat }}$ does not mean that this parameter does not have a large spatial variability, which can be confirmed by its sampling map (Figure 3D). In this case, it is observed 
that, although $\theta_{\text {sat }}$ has little sample amplitude, this parameter varies considerably in space. Likewise, the parameter $n$ presents low sample variance and a more uniform spatial distribution than the previous parameters.

Some reasons can be mentioned for the spatial variability of these variables. Firstly, the different soil covers during sampling. In the first sampling the soil was covered with the winter crop (oats and wheat), in the second the soil was covered by the remaining straw of these crops and in the third sampling the summer crop (soybean) was already being grown. In addition, between one crop and the other there was also the transit of machines.

Soil management also influences natural soil heterogeneity (Camargo et al., 2010), promoting variations in organic material accumulation, water movement, compaction and water erosion (Novaes Filho et al., 2007). This is in agreement with the work of Deb \& Shukla (2012), who pointed out that the value of $\mathrm{K}_{\text {sat }}$ varies according to the use of the soil as follows: forested areas $>$ no-tillage $>$ conventional tillage. These authors also comment that samplings over time have the greatest impact on $\mathrm{K}_{\text {sat }}$ variability, followed by land use. This fact explains why the $\mathrm{K}_{\text {sat }}$ values are so different, since the samples were collected in different periods, because the number of samples precludes the occurrence of only one set of samples.

Second, samples at $30 \mathrm{~cm}$, close to the soil surface, are more heterogeneous and this increases the variability found for most of the analyzed variables, mainly $\mathrm{K}_{\text {sat }}$. The same was confirmed by Hu et al. (2007), who verified that the influence of the variability of $\mathrm{K}_{\text {sat }}$ obtained at the soil surface on water flow is much greater than that of $\mathrm{K}_{\text {sat }}$ sampled at greater depths. Therefore, it is more appropriate to consider the spatial variability of $\mathrm{K}_{\text {sat }}$ in the surface.

It is possible that the large $\mathrm{K}_{\text {sat }}$ variability is also due to the size of the undisturbed samples collected. Bagarello \& Provenzano (1996) estimated the hydraulic conductivity in the laboratory using a variable head permeameter (method of this study) and verified that, in general, larger samples produced estimates with smaller values and lower variability than the samples obtained with smaller cylinders (as was the case in the present study). The authors explain that the reason for this difference is that in the small samples the preferential flow increases significantly.

In addition, the lowest values of $\mathrm{K}_{\text {sat }}$ were obtained in the lower parts of the terrain (concave areas), where the soil was more compacted (as verified during samplings). This is because soil compaction destroys the macropores, reducing the variability of the hydraulic conductivity. According to Souza et al. (2003), these areas are less influenced by the effects of erosion when compared to the convex or flat areas. The authors also add that, in general, the spatial variability of soil properties behaves according to an arrangement defined by factors such as management, erosion and landscape, and not only randomly (randomness of the phenomenon).

Based on these results, it can be expected that the heterogeneity of the aforementioned soil physical and hydraulic properties may result in significant differences in the estimates of other hydraulic or hydrological variables that depend on these properties, such as surface runoff, drains for agricultural drainage, availability of water for irrigation, irrigation water demands, etc. For example, as mentioned by Reichardt et al. (2001), considering soil heterogeneity remains a challenge for the management of agricultural practices, such as irrigation. Since the determination of the irrigation water depths depends on the soil moisture before application, retention and storage capacity, soil density, among other factors, it is obvious that the spatial variability of these properties is of extreme relevance for areas to be irrigated.

\section{Conclusions}

1. There is great variability of the hydraulic properties, represented by the saturated hydraulic conductivity and the parameters of the water retention curve in the soil.

2. The soil heterogeneity found in the study is probably much more influenced by temporal than spatial variability of the phenomenon itself, since the samples were not obtained simultaneously.

3. The soil types in the Donato stream basin are susceptible to compaction, which influences the heterogeneity of saturated hydraulic conductivity and the water retention curve in the soil, demonstrated by the spatial distribution of these parameters according to the regions where the soil was more compacted during the samplings.

\section{Acknowledgments}

We are very thankful to Conselho Nacional de Desenvolvimento Científico e Tecnológico (CNPq, Brazil) for the doctoral scholarship of the first author and the reviewers of this paper for their special contribution. We also thank the technicians and trainees of the Sediment Laboratory of the Instituto de Pesquisas Hidráulicas da Universidade Federal do Rio Grande do Sul (UFRGS), where all the tests were carried out and the results gave support to this study.

\section{Literature Cited}

Arraes, F. D. D. Modelagem bidimensional do movimento da água em condições de solo não saturado. Piracicaba: Escola Superior de Agricultura "Luiz de Queiroz", 2014. 86p. Tese Doutorado

Bagarello, V.; Provenzano, G. Factors affecting field and laboratory measurement of saturated hydraulic conductivity. Transactions of the American Society of Agricultural Engineers, v.39, p.153-159, 1996. https://doi.org/10.13031/2013.27493

Bergamin, A. C.; Vitorino, A. C. T.; Franchini, J. C.; Souza, C. M. A. de; Souza, F. R. de. Compactação em um Latossolo Vermelho Distroférrico e suas relações com o crescimento radicular do milho. Revista Brasileira de Ciência do Solo, v.34, p.681-691, 2010. https://doi.org/10.1590/S0100-06832010000300009

Camargo, L. A.; Marques Júnior, J.; Pereira, G. T. Spatial variability of physical attributes of an Alfisol under different hillslope curvatures. Revista Brasileira de Ciência do Solo, v.34, p.617-630, 2010. https://doi.org/10.1590/S0100-06832010000300003

Castro, N. M. dos R.; Chevallier, P.; Goldenfum, J. Recursos hídricos - Projeto Potiribu atualização 1989-1998: Dados básicos de fluviometria e pluviometria. Porto Alegre: Instituto de Pesquisas Hidráulicas da UFRGS, 2000. 67p. 
Champo, R. S.; Zamarrón, G. S. H. Convergence analysis for Latinhypercube lattice-sample selection strategies for 3D correlated random hydraulic-conductivity fields. Geofísica Internacional, v.49, p.131-140, 2010.

Coppola, A.; Basile, A.; Comegna, A.; Lamaddalena, N. Monte Carlo analysis of field water flow comparing uni- and bimodal effective hydraulic parameters for structured soil. Journal of Contaminant Hydrology, v.104, p.153-165, 2009. https://doi.org/10.1016/j. jconhyd.2008.09.007

Deb, S. K.; Shukla, M. K. Variability of hydraulic conductivity due to multiple factors. American Journal of Environmental Science, v.8, p.489-502, 2012. https://doi.org/10.3844/ajessp.2012.489.502

Fang, Z.; Bogena, H.; Kollet, S.; Vereecken, H. Scale dependent parameterization of soil hydraulic conductivity in 3D simulation of hydrological processes in a forested headwater catchment. Journal of Hydrology, v.536, p.365-375, 2016. https://doi. org/10.1016/j.jhydrol.2016.03.020

Furtunato, O. M.; Montenegro, S. M. G. L.; Antonino, A. C. D.; Oliveira, L. M. M. de; Souza, E. S. de; Moura, A. E. S. S. de. Variabilidade espacial de atributos físico-hídricos de solos em uma bacia experimental no estado de Pernambuco. Revista Brasileira de Recursos Hídricos, v.18, p.135-147, 2013. https:// doi.org/10.21168/rbrh.v18n2.p135-147

Genuchten, M. T. van. A closed form equation for predicting the hydraulic conductivity of unsaturated soils. Soil Science Society of America Journal, v.44, p.892-898, 1980. https://doi.org/10.2136/ sssaj1980.03615995004400050002x

Genuchten, M. T. van; Leij, F. J.; Yates, S. R. The RETC code for quantifying the hydraulic functions of unsaturated soils. Riverside: U.S. Salinity Laboratory, 1991. 93p.

Hu, K.; White, R. E.; Chen, D.; Li, B.; Li, W. Stochastic simulation of water drainage at the field scale and its application to irrigation management. Agricultural Water Management, v.89, p.123-130, 2007. https://doi.org/10.1016/j.agwat.2006.12.010

Hu, W.; Shao, M. A.; Wang, Q. J.; Fan, J.; Reichardt, K. Spatial variability of soil hydraulic properties on a steep slope in the loess plateau of China. Scientia Agricola, v.65, p.268-276, 2008. https:// doi.org/10.1590/S0103-90162008000300007
Medeiros, J. D. F. de. Variabilidade espacial do conteúdo de água no solo na Bacia do Arroio Donato-RS. Porto Alegre: UFRGS, 2004. 141p. Tese Doutorado

Montzka, C.; Herbst, M.; Weihermüller, L.; Verhoef, A.; Vereecken, H. A global data set of soil hydraulic properties and sub-grid variability of soil water retention and hydraulic conductivity curves. Earth System Science Data, v.9, p.529-543, 2017. https:// doi.org/10.5194/essd-9-529-2017

Novaes Filho, J.; Couto, E. G.; Oliveira, V. A. de; Johnson, M. S.; Lehmann, J.; Riha, S. S. Variabilidade espacial de atributos físicos de solo usada na identificação de classes pedológicas de microbacias na Amazônia meridional. Revista Brasileira de Ciência do Solo, v.31, p.91-100, 2007. https://doi.org/10.1590/ S0100-06832007000100010

Paleologos, E. K.; Sarris, T. S. Stochastic analysis of flux and head moments in a heterogeneous aquifer system. Stochastic Environmental Research and Risk Assessment, v.25, p.747-759, 2011. https://doi.org/10.1007/s00477-011-0459-7

Reichardt, K.; Silva, J. C. de A.; Bassoi, L. H.; Timm, L. C.; Oliveira, J. C. M. de; Bacchi, O. O. S.; Pilotto, J. E. Soil spatial variability and the estimation of the irrigation water depth. Scientia Agricola, v.58, p.549-553, 2001. https://doi.org/10.1590/S010390162001000300017

Santos, K. S.; Montenegro, A. A. A.; Almeida, B. G. de; Montenegro, S. M. G.; Andrade, T. da S.; Fontes Júnior, R. V. de P. Variabilidade espacial de atributos físicos em solos de vale aluvial no semiárido de Pernambuco. Revista Brasileira de Engenharia Agrícola e Ambiental, v.16, p.828-835, 2012. https://doi.org/10.1590/S141543662012000800003

Souza, C. K.; Marques Júnior, J.; Martins Filho, M. V.; Pereira, G. T. Influência do relevo e erosão na variabilidade espacial de um Latossolo em Jaboticabal (SP). Revista Brasileira de Ciência do Solo, v.27, p.1067-1074, 2003. https://doi.org/10.1590/S010006832003000600011

Taskinen, A.; Sirviö, H.; Bruen, M. Generation of two-dimensionally variable saturated hydraulic conductivity fields: Model theory, verification and computer program. Computers \& Geosciences, v.34, p.876-890, 2008. https://doi.org/10.1016/j.cageo.2007.04.010 